\title{
Article
}

\section{New Insights of the Fenton Reaction Using Glycerol as Experimental Model. Effect of O, Inhibition by Mg, and Oxidation State of Fe} Arturo Alberto Vitale, Eduardo Alberto Bernatene, Martin Gustavo Vitale, and Alicia Beatriz Pomilio J. Phys. Chem. A, Just Accepted Manuscript • Publication Date (Web): 24 Jun 2016

Downloaded from http://pubs.acs.org on June 24, 2016

\section{Just Accepted}

"Just Accepted" manuscripts have been peer-reviewed and accepted for publication. They are posted online prior to technical editing, formatting for publication and author proofing. The American Chemical Society provides "Just Accepted" as a free service to the research community to expedite the dissemination of scientific material as soon as possible after acceptance. "Just Accepted" manuscripts appear in full in PDF format accompanied by an HTML abstract. "Just Accepted" manuscripts have been fully peer reviewed, but should not be considered the official version of record. They are accessible to all readers and citable by the Digital Object Identifier (DOI®). "Just Accepted" is an optional service offered to authors. Therefore, the "Just Accepted" Web site may not include all articles that will be published in the journal. After a manuscript is technically edited and formatted, it will be removed from the "Just Accepted" Web site and published as an ASAP article. Note that technical editing may introduce minor changes to the manuscript text and/or graphics which could affect content, and all legal disclaimers and ethical guidelines that apply to the journal pertain. ACS cannot be held responsible for errors or consequences arising from the use of information contained in these "Just Accepted" manuscripts. 
New Insights of the Fenton Reaction Using Glycerol as Experimental Model. Effect of $\mathrm{O}_{2}$, Inhibition by $\mathrm{Mg}^{2+}$, and Oxidation State of Fe.

Arturo Alberto Vitale ${ }^{a^{*}}$, Eduardo A. Bernatene ${ }^{b}$, Martín Gustavo Vitale ${ }^{c}$, and Alicia Beatriz Pomilio $^{a, b}$

${ }^{a}$ Universidad de Buenos Aires. Area Hematología, Departamento de Bioquímica Clínica, Hospital de Clínicas “José de San Martín”, Av. Córdoba 2351, C1120AAR Buenos Aires, Argentina. email: avitale@ffyb.uba.ar.

b Instituto de Bioquímica y Medicina Molecular (IBIMOL, CONICET-UBA), Junín 956, Buenos Aires, Argentina.

${ }^{c}$ Universidad de Buenos Aires. Hospital Infanto Juvenil "Dra. Carolina Tobar García". Doctor Ramón Carrillo 315, Buenos Aires, Argentina.

\section{${ }^{*}$ Corresponding Author \\ Dr. Arturo A. Vitale \\ Email: aavitale@sinectis.com.ar aavitale@gmail.com avitale@ffyb.uba.ar \\ Telephone: +541148143952}

\section{Author Contributions}

All authors have given approval to the final version of the manuscript.

The authors declare no competing financial interest. 


\section{ABSTRACT}

The use of iron ions as catalyst of oxidation with hydrogen peroxide, known as Fenton reaction, is important for industry and biological systems. It has been widely studied since its discovery in the $19^{\text {th }}$ century, but important aspects of the reaction as which is the oxidant, the role of oxygen, and the oxidation state of Fe still remain unclear.

In this work new mechanistic insights of the oxidation of carbohydrates by the Fenton reaction using glycerol as experimental model are described. The reaction was studied by means of Oxidation Reduction Potential (ORP) measures. The stoichiometry was measured, showing the important role of oxygen for lowering $\mathrm{H}_{2} \mathrm{O}_{2}$ consumption under aerobic conditions. Evidence is provided to demonstrate that in this system $\mathrm{Fe}^{2+}$ generates a catalyst by reacting with a substrate to produce a complex, which gives rise to singlet oxygen after reacting with $\mathrm{H}_{2} \mathrm{O}_{2}$.

This is the first time that the inhibitor effect of $\mathrm{Mg}^{2+}$ is reported in this reaction, and its participation in the mechanism is described.

A rational mechanism for the oxidation of glycerol using the Fenton reaction under these specific conditions is proposed. The role of oxygen, the participation of $\mathrm{Fe}^{2+}$, and the inhibition by $\mathrm{Mg}^{2+}$ are fully demonstrated experimentally. 


\section{INTRODUCTION}

The Fenton reaction is known since 1894, when Fenton described the oxidation of tartaric acid with hydrogen peroxide in the presence of $\mathrm{Fe}^{2+}$ ions. ${ }^{1}$ However, according to von Sonntag ${ }^{2}$ the use of iron ions as catalyst of oxidation with hydrogen peroxide was described four decades before by Schönbein ${ }^{3}$ in 1857 for the oxidation of iodide with $\mathrm{H}_{2} \mathrm{O}_{2}$ in the presence of $\mathrm{Fe}^{2+}$. The Fenton reaction has important industrial applications, ${ }^{4}$ and in biological systems. ${ }^{5}$ In the 20th century, Haber and Weiss ${ }^{6}$ studied exhaustively the decomposition of hydrogen peroxide with iron ions, and proposed the formation of the hydroxyl radical, $\mathrm{HO}$. This mechanism was criticized by several authors. ${ }^{7}$ Bray and Gorin, ${ }^{8}$ and Barb et al. ${ }^{9}$ proposed the occurrence of $\left(\mathrm{H}_{2} \mathrm{O}\right)_{5} \mathrm{~F} e^{\mathrm{IV}}=\mathrm{O}$ (ferryl). In 1984 Sugimoto and Sawyer ${ }^{10}$ proposed that the products of the Fenton reaction with 1,2-diphenylethylene in acetonitrile were typical of the presence of singlet oxygen. The kinetics of this reaction was studied recently in detail by Rachmilovich-Calis et al. ${ }^{11}$ where they reported evidence for $\mathrm{Fe}\left(\mathrm{H}_{2} \mathrm{O}\right)_{6}{ }^{2+}$. In $1999 \mathrm{Kremer}^{12}$ showed that $\mathrm{FeO}^{2+}$ acts as the key intermediate. Fenton chemistry at aqueous interfaces was also studied. ${ }^{13}$ There are several and exhaustive reviews about the Fenton reaction, ${ }^{2,14,15}$ however the mechanism has not been yet fully elucidated, as stated by von Sonntag, ${ }^{2}$ and Barbusinski. ${ }^{14}$ In a 2015 paper $^{16}$ there is still a discussion about the existence of HO radical.

There are important aspects of the reaction that still remain unclear according to Sonntag, ${ }^{2}$ and Barbusinski, ${ }^{14}$ as follows

(a) Which is the oxidant, e.g., hydroxyl radical, ferryl ion, or singlet oxygen.

(b) Which is the stoichiometry of the Fenton reaction. How much hydrogen peroxide is consumed by the organic compound, and which is the effect of oxygen. Ingles ${ }^{17}$ in 1972 reported that the amount of hydrogen peroxide consumed in titration of carbohydrates in 
the presence of iron was higher if air was excluded from the system. The same effect was also described for aniline. ${ }^{18}$

(c) Why the reaction is slower when $\mathrm{Fe}^{3+}$ is used instead of $\mathrm{Fe}^{2+}$.

First of all, it is necessary to point out what is called "Fenton reaction". There is some misunderstanding in literature between two reactions that are not the same, (a) The original reaction described by Fenton in 1894 that was the oxidation of organic compounds by hydrogen peroxide in the presence of iron ions, and (b) the Haber - Weiss cycle of decomposition of hydrogen peroxide in the presence of iron ions, without organic compounds. We should be clear about this definition to know what we are talking about.

In this paper we studied the Fenton reaction according to the definition "The oxidation of organic compounds by hydrogen peroxide in the presence of iron ions".

The aim of this work is to elucidate several mechanistic aspects of the oxidation of carbohydrates by the Fenton reaction using glycerol as model compound with the evidence obtained from experiments performed in our laboratories, and to propose a mechanism according to these results, comparing them with those of literature.

\section{EXPERIMENTAL}

Several procedures were used to study the Fenton reaction, as example it is worth to mention redox titration, ${ }^{17}$ cyclic voltametry, ${ }^{19}$ COD (Chemical Oxygen Demand), ${ }^{20}$ ORP (oxidation-reduction potential measurement), ${ }^{21}$ stop flow spectrometry, ${ }^{11}$ and UV spectroscopy. ${ }^{12}$ In this work we applied several of the methods mentioned above like ORP, $\mathrm{UV}, \mathrm{COD}$, and $\mathrm{H}^{+}$concentration. We used some of them together in the same reaction batch that led us to get accurate information about the mechanism. Moreover, we took into account the use of iron ion only in catalytic concentration referred to $\mathrm{H}_{2} \mathrm{O}_{2}$, thus being the 
ratio $\mathrm{Fe}^{2+} / \mathrm{H}_{2} \mathrm{O}_{2}<10^{-1}$, similar as that reported by several authors for the treatment of wastes. $^{22}$

Instrumental. ORP was measured with HI 323 OB electrode (HANNA) calibrated with the standard solution HI 7022L (470 mV), and recorded with a computer interface (PROSKIT 1860 MT). COD was measured with COD Thermo Reactor, and DR2000 spectrophotometer (Hach Company). UV was measured with a spectrophotometer UV-Vis M-1700 (Metrolab). All chemicals were purchased from Aldrich. $\mathrm{H}_{2} \mathrm{O}_{2}$ was titrated with $\mathrm{KMnO}_{4}$ before each set of reactions. All experiments were carried out by triplicate, under temperature control.

Reaction in the presence of oxygen: A $100 \mathrm{ml}$ beaker provided with ORP and glass electrodes, thermometer, and a magnetic stirrer was placed in a thermostatized bath, 50 $\mathrm{ml}$ of water with the desired concentration of substrate was added, and the $\mathrm{pH}$ was adjusted with diluted $\mathrm{H}_{2} \mathrm{SO}_{4}(1 \%)$. When the temperature was stabilized, solid $\mathrm{FeSO}_{4} .7 \mathrm{H}_{2} \mathrm{O}$ was poured in, and the solution was stirred vigorously to favor air oxygen dissolution (Figure 1, point A). The required amount of $\mathrm{H}_{2} \mathrm{O}_{2}$ was added, this time was taken as $\mathbf{t}_{0}$ of the reaction (Figure 1, point $\mathbf{B}$ ), which was also indicated by the appearance of a yellow color (absorbance, $\lambda 460 \mathrm{~nm}$ ) that stayed along the reaction, and faded down at the end of it. The reaction was followed by ORP recording $[E(m V) v s . t(s)]$ until the ORP reached a minimum, and then stayed constant (Figure 1, point E). When the ORP began to drop (Figure 1, point C), 100 ul aliquots were taken to check the disappearance of $\mathrm{H}_{2} \mathrm{O}_{2}$ by the standard $\mathrm{K}_{2} \mathrm{Cr}_{2} \mathrm{O}_{7}$ test (a green-blue color appeared in the presence of minute amounts of $\mathrm{H}_{2} \mathrm{O}_{2}$ ). When the test was negative, the end of the reaction was reached, and the whole $\mathrm{H}_{2} \mathrm{O}_{2}$ was consumed. This matched the ORP maximum slope (Figure 1, point D) that was checked by the first derivative. 


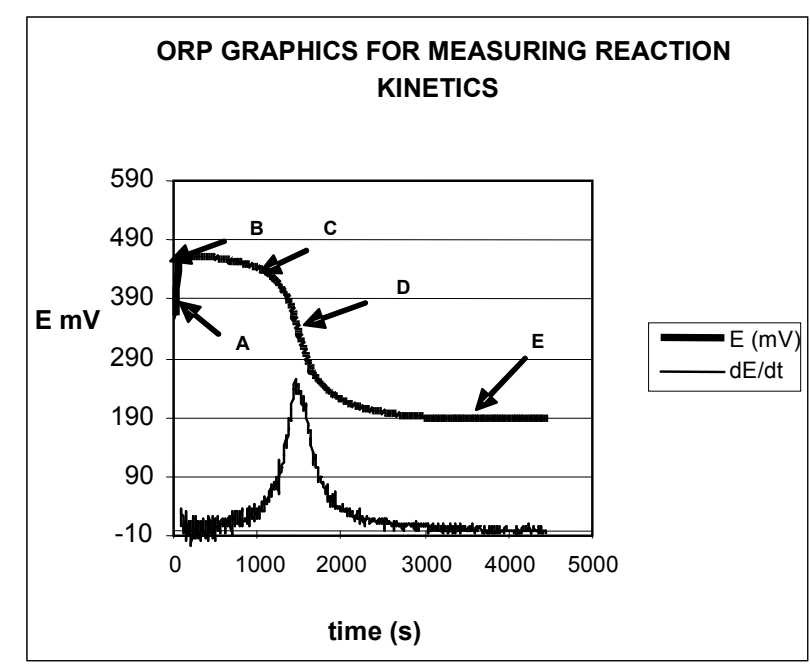

A: before adding $\mathrm{H}_{2} \mathrm{O}_{2}$, B: just after adding $\mathrm{H}_{2} \mathrm{O}_{2}$ C: just after consuming all $\mathrm{H}_{2} \mathrm{O}_{2}$ D: ORP maximum slope, Negative reaction to $\mathrm{K}_{2} \mathrm{Cr}_{2} \mathrm{O}_{7} / \mathrm{H}^{+}$. E: ORP reaching a minimum, and staying constant.

Figure 1. Change of ORP, and first derivative during the Fenton reaction.

Reaction in the absence of oxygen. A $100 \mathrm{ml}$ four neck flask provided with an ORP and glass electrodes, a thermometer, a rubber septum, and a magnetic stirrer was placed in a thermostatized bath, $50 \mathrm{ml}$ of water with the desired concentration of substrate was added, the $\mathrm{pH}$ was adjusted, and the temperature was stabilized. Nitrogen was bubbled through the rubber septum with a needle connected to a nitrogen tank and another needle for the exhaust. After bubbling for 30 minutes, solid $\mathrm{FeSO}_{4} \cdot 7 \mathrm{H}_{2} \mathrm{O}$ was quickly poured in under positive nitrogen pressure to avoid air. When the salt was dissolved, the required amount of $\mathrm{H}_{2} \mathrm{O}_{2}$ was added by syringe and needle through the rubber septum. All the reaction was performed under nitrogen, and samples were taken with a syringe.

Reaction for stoichiometric purposes. In both cases, with and without oxygen, $\mathrm{H}_{2} \mathrm{O}_{2}$ was added dropwise until ORP remained constant in the upper value (Figure 1, point B), the positive dichromate test showed an excess of $\mathrm{H}_{2} \mathrm{O}_{2}$, and iron hydroxides precipitates began to appear. 
$\mathrm{H}^{+}$Concentration. It was recorded with the glass electrode as $\mathrm{mV} v s$. $\mathrm{t}(\mathrm{s})$ instead of plotting $\mathrm{pH}$ vs. $\mathrm{t}$ for comparison with ORP in the same units. Moreover, $\mathrm{mV}$ vs. $\mathrm{t}$ plots are directly proportional to $\mathrm{H}^{+}$concentration.

COD. It was measured at the beginning and at the end of the reaction, when required.

Measure of $\mathrm{Fe}^{2+}$ and $\mathrm{Fe}^{3+}$ concentration. Concentration of different species of iron were measured by the standard o-phenanthroline method. ${ }^{23} \mathrm{~A}$ calibration curve was built by plotting the absorbance at $510 \mathrm{~nm}$ of the $\mathrm{Fe}^{2+}$ complex with o-phenanthroline $(0.3 \%$ solution in water at $\mathrm{pH} 2.5) . \mathrm{Fe}^{3+}$ was measured after reduction to $\mathrm{Fe}^{2+}$ with $\mathrm{NH}_{2} \mathrm{OH}(10 \%$ in water at $\mathrm{pH} 2.5)$.

Rate measures and calculations. Except for stoichiometric measurements, $\mathrm{H}_{2} \mathrm{O}_{2}$ was always used in shortage respect of the substrate to avoid side reactions with free iron when the substrate was exhausted. In this work we measured the time in which a known amount of $\mathrm{H}_{2} \mathrm{O}_{2}$ was consumed according to Figure 1, ( $\left.\mathbf{t}_{\mathbf{D}}-\mathbf{t}_{\mathbf{B}}\right)$. Reaction (1). For calculating $\mathbf{k}$ and other kinetics parameters we used the half life method, $\mathrm{t}_{1 / 2}$ (time required for a known amount of $\mathrm{H}_{2} \mathrm{O}_{2}$ decreasing by $50 \%$ ). Reactions (2), and (3). To check whether $\mathrm{H}_{2} \mathrm{O}_{2}$ was consumed in a linear way, a sample reaction was stopped at $\mathrm{t}_{1 / 2}$ by rising $\mathrm{pH}$ to 10 with $0.1 \mathrm{M} \mathrm{NaOH}$ to precipitate iron hydroxides. After filtering, the $\mathrm{pH}$ was adjusted again to 2.0 , and the residual $\mathrm{H}_{2} \mathrm{O}_{2}$ was titrated by permanganimetry. The concentration of $\mathrm{H}_{2} \mathrm{O}_{2}$ was just half of the initial.

$$
\begin{aligned}
\Delta t(s) & =\left(t_{D}-t_{B}\right) \\
\ln \left(0.5\left[\mathrm{H}_{2} \mathrm{O}_{2}\right]_{0} /\left[\mathrm{H}_{2} \mathrm{O}_{2}\right]_{0}\right) & =\ln (0.5)=-k t_{1 / 2} \\
k & =0.693 / t_{1 / 2}
\end{aligned}
$$




\section{RESULTS AND DISCUSSION}

\section{Stoichiometry}

It is very important to know the stoichiometry of the Fenton reaction to get a deep insight into the mechanism. Data about this topic is scarce, there are few papers about this subject. ${ }^{17,4,24,25}$ Ingles $^{17}$ used the Fenton reaction with almost stoichiometric amount of iron to titrate carbohydrates, performing accurate measures of the uptake of hydrogen peroxide. He found that the required hydrogen peroxide was lesser if the reaction was carried out in the presence of oxygen than without it, pointing out the importance of oxygen in the Fenton reaction, but not investigating thoroughly the mechanistics of this result.

We tried several substrates, and we chose carbohydrates to study the mechanism of the Fenton reaction because they have antioxidant activity ${ }^{26,27}$ and their reactions have a neat end point that helps to analyze the experimental results. ${ }^{17}$

One set of reactions was performed in the presence of air with fast stirring to allow a quick exchange with the oxygen of air for keeping constant the $\mathrm{O}_{2}$ concentration in the solution $\left(3.110^{-4} \mathrm{M}\right.$ at $\left.20^{\circ} \mathrm{C}\right)$.

Another set of reactions was performed in the absence of oxygen by degassing the solution with nitrogen.

In all reactions, the total oxidation of the organic substrate by hydrogen peroxide was verified by an independent method. COD measures were performed at the beginning and at the end of the reactions to check the absence of organic oxidizable matter.

The reactions were carried out at temperatures between $20^{\circ} \mathrm{C}$ and $50^{\circ} \mathrm{C}$ that can be found in an industrial plant that uses this method for destroying organic wastes. Below $20^{\circ} \mathrm{C}$ the reaction is too slow, and over $50^{\circ} \mathrm{C} \mathrm{H}_{2} \mathrm{O}_{2}$ begins to decompose. 
We selected substrates in which the reaction was slow enough to measure the rate parameters minimizing error, taking into account that this is a heterogeneous reaction under fast stirring when it is performed in the presence of air.

The following substrates were studied, glycerol, sucrose, mannitol, lactose, glucose, fructose, and tartaric acid.

In all cases, it can be observed that the consumption of $\mathrm{H}_{2} \mathrm{O}_{2}$ is lesser with oxygen than without oxygen (Table 1). The reaction was performed by triplicate, and at different days. The relationship between consumed hydrogen peroxide and substrate was always the same for each compound.

Table 1. Stoichiometric intake of $\mathrm{H}_{2} \mathrm{O}_{2}$ with and without $\mathrm{O}_{2}$, and comparison with $\mathrm{CDO}$

\begin{tabular}{|c|c|c|c|c|}
\hline (S) & A & B & $\begin{array}{c}\text { CDO } \\
\text { initial }\end{array}$ & $\begin{array}{c}\text { CDO } \\
\text { Final }\end{array}$ \\
\hline Gly & $4.1 \pm 0.1$ & $7.3 \pm 0.1$ & $2391 \pm 10$ & $<10$ \\
\hline Suc & $11.7 \pm 0.1$ & $24.8 \pm 0.1$ & $2231 \pm 10$ & $<10$ \\
\hline Man & $6.7 \pm 0.1$ & $13.2 \pm 0.1$ & $2245 \pm 10$ & $<10$ \\
\hline Lac & $11.5 \pm 0.1$ & $24.3 \pm 0.1$ & $2229 \pm 10$ & $<10$ \\
\hline Glu & $6.0 \pm 0.1$ & $12.5 \pm 0.1$ & $2120 \pm 10$ & $<10$ \\
\hline Fru & $6.0 \pm 0.1$ & $12.3 \pm 0.1$ & $2125 \pm 10$ & $<10$ \\
\hline Tar & $3.1 \pm 0.1$ & $5.2 \pm 0.1$ & $1050 \pm 10$ & $<10$ \\
\hline
\end{tabular}

Concentration of the substrate $(\mathbf{S})=2.0 \pm 0.1 \mathrm{mg} / \mathrm{ml} ; \mathrm{Fe}^{2+}=1.5 \pm 0.1 \times 10^{-3} \mathrm{M} ; \mathrm{T} 20^{\circ} \mathrm{C} ; \mathrm{pH} 2.5 \pm$ 0.1. $\mathbf{C D O}=\mathrm{mg} \mathrm{O}_{2} / \mathrm{l}$. A $=$ mmol $\mathrm{H}_{2} \mathrm{O}_{2} / \mathrm{mmol} \mathrm{S}$ (with $\mathrm{O}_{2}$ ); $\mathbf{B}=\mathrm{mmol}_{2} \mathrm{O}_{2} / \mathrm{mmol} \mathrm{S}$ (without $\mathrm{O}_{2}$ ). Gly (Glycerol); Suc (Sucrose); Man (Mannitol); Lac (Lactose); Glu (Glucose); Fru (Fructose); Tar (Tartaric Acid). Reaction blanks for each compound were carried out without $\mathrm{H}_{2} \mathrm{O}_{2}$ in the presence of air for $300 \mathrm{~min}$; precipitates of iron oxides were the only products. Initial and final CODs were the same.

\section{Measure of reaction rates}

For the measure of the reaction rates, $\mathrm{H}_{2} \mathrm{O}_{2}$ was always used in shortage with respect to the substrate to avoid side reactions with free iron when the substrate was exhausted. In this work we measured the time in which a known amount of $\mathrm{H}_{2} \mathrm{O}_{2}$ was consumed (Table 2).

Different rates of reaction were observed, the reaction of tartaric acid being the fastest, and that of glycerol being the slowest. Consequently, glycerol was chosen as model 
compound to carry out a detailed study of the kinetics, and other parameters of the reaction. As the reaction was slower, the error in the measures was smaller.

Table 2. Reaction rate for different substrates using $t_{1 / 2}$ method

\begin{tabular}{|l|c|}
\hline Substrate (S) & $\mathbf{k}_{\mathbf{1}}(\mathbf{1} / \mathbf{s}) \times \mathbf{1 0}^{-\mathbf{3}}$ \\
\hline Glycerol & $\mathbf{2 . 6} \pm 0.1$ \\
\hline Sucrose & $4.9 \pm 0.1$ \\
\hline Mannitol & $6.6 \pm 0.1$ \\
\hline Lactose & $6.6 \pm 0.1$ \\
\hline Glucose & $13.7 \pm 0.1$ \\
\hline Fructose & $26.2 \pm 0.1$ \\
\hline Tartaric acid & $38.7 \pm 0.1$ \\
\hline
\end{tabular}

S $(2.0 \pm 0.1 \mathrm{mg} / \mathrm{ml}) ; \mathrm{H}_{2} \mathrm{O}_{2}\left(3.0 \pm 0.1 \times 10^{-2} \mathrm{M}\right) ; \mathrm{Fe}^{2+}\left(1.5 \pm 0.1 \times 10^{-3} \mathrm{M}\right) ; \mathrm{T} 20.0 \pm 0.1^{\circ} \mathrm{C}$ with $\mathrm{O}_{2}$

\section{Effect of the initial $\mathrm{pH}$ and $\mathrm{H}^{+}$variation during the reaction}

The reaction was performed with glycerol at $\mathrm{pH} 2.0$ and 2.5. A larger $\mathrm{pH}$ difference could not be used because at $\mathrm{pH}$ higher than 2.6 iron hydroxides began to precipitate, and at $\mathrm{pH}$ lower than 1.8 the reaction did not start. These measures provided important data to elucidate the reaction mechanism (Table 3). Other results about this subject have been previously reported, ${ }^{28}$ but they were referred to the decomposition of $\mathrm{H}_{2} \mathrm{O}_{2}$ in the presence of iron ions without organic substrate.

Table 3. Rate of reaction at different $\mathrm{pH}$

\begin{tabular}{|c|c|}
\hline $\mathbf{p H}$ & $\mathbf{k}_{\mathbf{1}}(\mathbf{1} / \mathbf{s}) \times 10^{-3}$ \\
\hline 2.0 & $0.8 \pm 0.1$ \\
\hline 2.5 & $2.7 \pm 0.1$ \\
\hline
\end{tabular}

$$
\begin{gathered}
\text { Vol }=50 \mathrm{ml} ; \mathrm{T}=21^{\circ} \mathrm{C} ; \mathrm{Fe}^{2+}=2.0 \pm 0.1 \times 10^{-3} \mathrm{M} ; \\
\mathrm{H}_{2} \mathrm{O}_{2}=2.0 \pm 0.1 \times 10^{-2} \mathrm{M} ; \text { glycerol }=2.0 \pm 0.1 \times 10^{-2} \mathrm{M}
\end{gathered}
$$

A variation of the $\mathrm{H}^{+}$concentration was observed along the reaction, increasing continuously, and remaining constant at the end of the reaction. This was due to the production of carbonic acid as final product of the reaction with glycerol. This effect cannot be detected if the reaction is carried out in buffer. Both measures with an ORP electrode 
and a glass electrode to check $\mathrm{H}^{+}$concentration $(\mathrm{mV})$ are shown in Figure 2 in the same plot for comparative purposes.

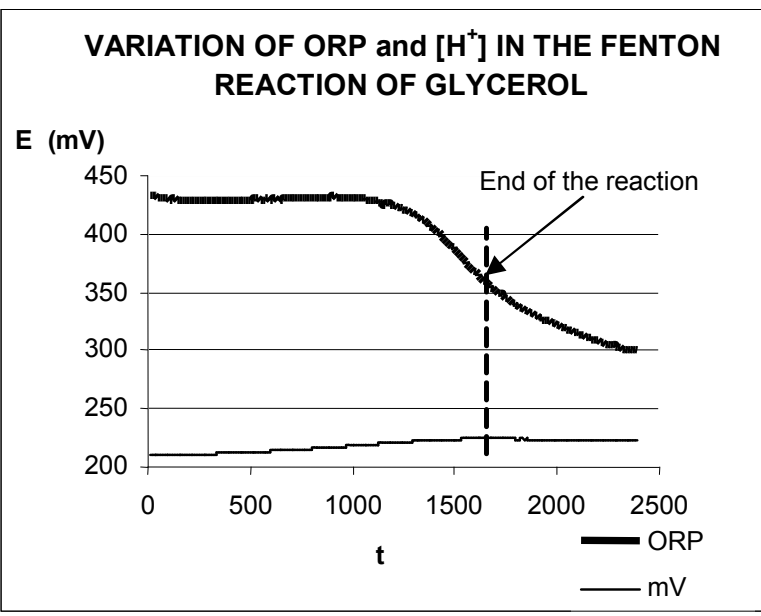

$$
\begin{gathered}
\text { Vol }=50 \mathrm{ml} ; \mathrm{T}=21.0 \pm 0.1^{\circ} \mathrm{C} ; \mathrm{Fe}^{2+}=2.0 \pm 0.1 \times 10^{-3} \mathrm{M} ; \\
\mathrm{H}_{2} \mathrm{O}_{2}=2.0 \pm 0.1 \times 10^{-2} \mathrm{M} ; \mathrm{pH}=2.5 \pm 0.1 ; \text { glycerol }=2.0 \pm 0.1 \times 10^{-2} \mathrm{M}
\end{gathered}
$$

Figure 2. Variation of ORP and $\mathrm{H}^{+}$in the Fenton reaction of glycerol

\section{Relationship between initial concentration of $\mathrm{H}_{2} \mathrm{O}_{2}$ and reaction rate}

The time of reaction according to different initial concentrations of $\mathrm{H}_{2} \mathrm{O}_{2}$ was studied

(Figure 3), showing that $\Delta \mathrm{t} / \Delta \mathrm{H}_{2} \mathrm{O}_{2}$ (slope of the plot) was linear with $r^{2}=0.991$. No difference in the reaction rate was found because of being independent of the initial concentration of $\mathrm{H}_{2} \mathrm{O}_{2}$. This result is in agreement with a catalytic reaction, in which $\mathrm{H}_{2} \mathrm{O}_{2}$ concentration does not affect the rate-determining step. 


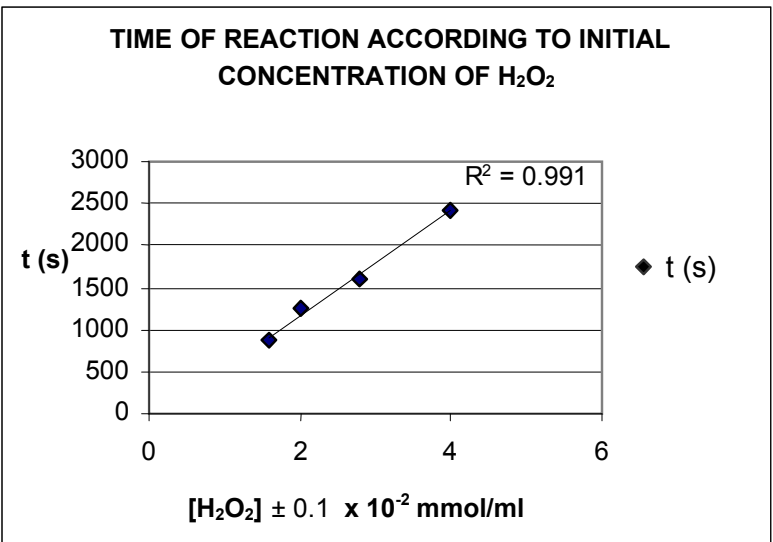

Figure 3. Time of reaction according to the initial concentration of $\mathrm{H}_{2} \mathrm{O}_{2}$

Effect of concentration of $\mathrm{Fe}^{2+}$ and $\mathrm{Fe}^{3+}$

The reaction rate for different initial concentrations of $\mathrm{Fe}^{2+}$ and $\mathrm{Fe}^{3+}$ was measured (Table 4), showing a linear dependence on iron ions.

When the reaction was started with $\mathrm{Fe}^{+3}$, it was at least 10 times slower than that started with $\mathrm{Fe}^{+2}$ at the same concentration (Table 4). This result provided important information about the mechanism as will be explained below.

Table 4. Reaction rate for different concentrations of $\mathrm{Fe}^{2+}$ and $\mathrm{Fe}^{3+}$

$$
\begin{array}{|c|c|c|c|}
\hline \mathbf{F e}^{2+} \mathbf{M} & \mathbf{k}_{1}(\mathbf{1} / \mathbf{s}) & \mathbf{F e}^{3+} \mathbf{M} & \mathbf{k}_{1}(\mathbf{1} / \mathbf{s}) \\
\hline 1.5 \pm 0.1 \times 10^{-3} & 1.10 \times 10^{-3} & 1.5 \times 10^{-3} & 7.6 \times 10^{-5} \\
\hline 2.0 \pm 0.1 \times 10^{-3} & 2.16 \times 10^{-3} & 2.0 \times 10^{-3} & 13.1 \times 10^{-5} \\
\hline 2.5 \pm 0.1 \times 10^{-3} & 4.70 \times 10^{-3} & 2.5 \times 10^{-3} & 23.7 \times 10^{-5} \\
\hline
\end{array}
$$

\section{Oxidation state of $\mathrm{Fe}$ in the Fenton reaction}

One important topic of the Fenton mechanism is the oxidation state of iron along the reaction. Different authors ${ }^{14}$ proposed that iron can participate as $\mathrm{Fe}^{2+}, \mathrm{Fe}^{3+}$, or $\mathrm{Fe}^{4+}$. To clear up this topic, we measured the concentration of iron species at the beginning and at the end of the reaction with the o-phenanthroline method (Table 5). In the experiments A, the reaction was started with $\mathrm{Fe}^{2+}$, and in experiment $\mathbf{B}$, it was started with $\mathrm{Fe}^{3+}$. 
When the reaction was started with $\mathrm{Fe}^{2+}$, at the end of the reaction the same amount of $\mathrm{Fe}^{2+}$ was found as at the beginning. Instead, when the reaction was started with $\mathrm{Fe}^{3+}$, at the end of the reaction we only found $\mathrm{Fe}^{2+}$ in an equivalent amount as that of $\mathrm{Fe}^{3+}$ added at the beginning of the reaction. This result means that iron participates as a catalyst only as $\mathrm{Fe}^{2+}$, and when the reaction was started with $\mathrm{Fe}^{3+}$, this iron species first had to be reduced to $\mathrm{Fe}^{2+}$ before the reaction begins. This reduction step slows down the reaction with $\mathrm{Fe}^{3+}$.

Table 5. Concentration of iron species by the o-phenanthroline method.

\begin{tabular}{|c|c|c|c|c|}
\hline Reaction & A & B & [C & D) \\
\hline $\mathbf{1}\left(\mathrm{Fe}^{2+}\right)$ & $1.5 \pm 0.1$ & 0 & $1.5 \pm 0.1$ & 0 \\
\hline $\mathbf{2}\left(\mathrm{Fe}^{3+}\right)$ & 0 & $1.5 \pm 0.1$ & $1.5 \pm 0.1$ & 0 \\
\hline $\mathbf{3}\left(\mathrm{Fe}^{2+}\right)$ & $2.0 \pm 0.1$ & 0 & $2.0 \pm 0.1$ & 0 \\
\hline $\mathbf{4}\left(\mathrm{Fe}^{3+}\right)$ & 0 & $2.0 \pm 0.1$ & $2.0 \pm 0.1$ & 0 \\
\hline $\mathbf{5}\left(\mathrm{Fe}^{2+}\right)$ & $2.5 \pm 0.1$ & 0 & $2.5 \pm 0.1$ & 0 \\
\hline $\mathbf{6}\left(\mathrm{Fe}^{3+}\right)$ & 0 & $2.5 \pm 0.1$ & $2.5 \pm 0.1$ & 0 \\
\hline
\end{tabular}

A $\left[\mathrm{Fe}^{2+}\right]$ initial $\left(10^{-3} \mathrm{M}\right) ; \mathbf{B}\left[\mathrm{Fe}^{3+}\right]$ initial $\left(10^{-3} \mathrm{M}\right) ; \mathbf{C}\left[\mathrm{Fe}^{2+}\right]$ final $\left(10^{-3} \mathrm{M}\right) ; \mathbf{D}\left[\mathrm{Fe}^{3+}\right]$ final $\left(10^{-3} \mathrm{M}\right)$

\section{Arrhenius parameters for $\mathrm{Fe}^{2+}$ and $\mathrm{Fe}^{3+}$}

To look for differences in the rate-determining step of the reaction with $\mathrm{Fe}^{2+}$ and $\mathrm{Fe}^{3+}$ we carried out the Arrhenius study for both reactions. Results are shown in Figure 4 and Table 6.

Table 6. Arrhenius data of Figure 5

\begin{tabular}{|c|c|c|c|c|c|}
\hline $\mathrm{T}^{\circ} \mathrm{C}$ & $\mathrm{T}^{\circ} \mathrm{K}$ & $t(s)$ & $1 / \mathrm{T} \times 10^{3}$ & $\begin{array}{l}\log k \\
\left(\mathrm{Fe}^{2+}\right)\end{array}$ & $\begin{array}{l}\log _{k} k \\
\left(\mathrm{Fe}^{3+}\right)\end{array}$ \\
\hline $22.0 \pm 0.1$ & $295 \pm 0.1$ & 960 & $3.39 \pm 0.01$ & $-2.8 \pm 0.1$ & $-3.8 \pm 0.1$ \\
\hline $31.0 \pm 0.1$ & $304 \pm 0.1$ & 480 & $3.28 \pm 0.01$ & $-2.5 \pm 0.1$ & $-3.6 \pm 0.1$ \\
\hline $41.0 \pm 0.1$ & $314 \pm 0.1$ & 240 & $3.18 \pm 0.01$ & $-2.2 \pm 0.1$ & $-3.3 \pm 0.1$ \\
\hline $51.0 \pm 0.1$ & $324 \pm 0.1$ & 150 & $3.08 \pm 0.01$ & $-2.0 \pm 0.1$ & $-3.1 \pm 0.1$ \\
\hline
\end{tabular}

$$
E_{a}\left(\mathrm{Fe}^{2+}\right)=50.8 \mathrm{~kJ} \mathrm{~mol}^{-1} \quad \mathrm{E}_{\mathrm{a}}\left(\mathrm{Fe}^{3+}\right)=48.3 \mathrm{~kJ} \mathrm{~mol}^{-1}
$$

Activation energies for $\mathrm{Fe}^{2+}$ and $\mathrm{Fe}^{3+}$ showed a difference of $2.5 \mathrm{~kJ} \mathrm{~mol}^{-1}$ that was within the experimental error. Therefore, the rate-determining step of the reaction was the 
same for both iron species. The difference in the rate of reaction was due to the initial $\mathrm{Fe}^{3+}$ to $\mathrm{Fe}^{2+}$ reduction step as mentioned above.

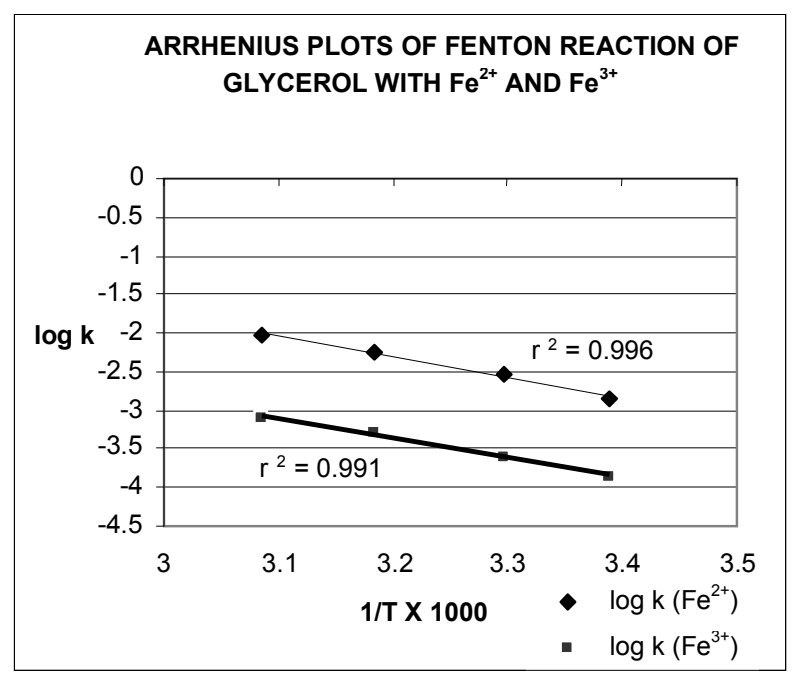

$$
\begin{gathered}
\mathrm{Vol}=50 \mathrm{ml} ; \mathrm{Fe}^{2+}=\mathrm{Fe}^{3+}=1.5 \pm 0.1 \times 10^{-3} \mathrm{M} ; \mathrm{H}_{2} \mathrm{O}_{2}=2.0 \pm 0.1 \times 10^{-2} \mathrm{mmol} / \mathrm{m} ; \mathrm{pH}=2.5 \pm 0.1 ; \\
\text { glycerol }=2.0 \pm 0.1 \times 10^{-2} \mathrm{M}
\end{gathered}
$$

Figure 4. Arrhenius plot of Fenton reaction of glycerol with $\mathrm{Fe}^{2+}$ and $\mathrm{Fe}^{3+}$.

\section{Effect of $\mathrm{Mg}^{2+}$ and $\mathrm{Ca}^{2+}$ in the Fenton reaction of glycerol}

Table 7. Comparative rate of the Fenton reaction of glycerol in the presence of $\mathrm{Mg}^{2+}$ and $\mathrm{Ca}^{2+}$ cations

\begin{tabular}{|c|c|}
\hline CATION & $\mathbf{k}_{\mathbf{1}}(\mathbf{1} / \mathbf{s})$ \\
\hline Without cation & $2.6 \times 10^{-3}$ \\
\hline $\mathrm{Mg}^{2+}$ & $0.6 \times 10^{-3}$ \\
\hline $\mathrm{Ca}^{2+}$ & $2.0 \times 10^{-3}$ \\
\hline
\end{tabular}

$\mathrm{Vol}=50 \mathrm{ml} ; \mathrm{T}=21^{\circ} \mathrm{C} ; \mathrm{Fe}^{2+}=2.0 \pm 0.1 \times 10^{-3} \mathrm{M} ; \mathrm{H}_{2} \mathrm{O}_{2}=2.0 \pm 0.1 \times 10^{-2} \mathrm{M} ; \mathrm{pH}=2.5 ;$ glycerol $=$ $2.0 \pm 0.1 \times 10^{-2} \mathrm{M}, \mathrm{Mg}^{2+}=4.0 \pm 0.1 \times 10^{-3} \mathrm{M} ; \mathrm{Ca}^{2+}=4 \pm 0.1 \times 10^{-3} \mathrm{M}$

We studied the incidence of $\mathrm{Mg}^{2+}$ and $\mathrm{Ca}^{2+}$ (Table 7). These are cations of biological importance, ${ }^{29}$ and can be also found in wastes that are prone to Fenton treatment. Data in literature about this subject is scarce. ${ }^{30}$

A higher effect was observed with $\mathrm{Mg}^{2+}$ (the reaction was slower than with $\mathrm{Ca}^{2+}$ ). Therefore, a detailed study was carried out with this cation. 
A set of reactions with a different $\mathrm{Mg}^{2+} / \mathrm{Fe}^{2+}$ ratio was performed as shown in Table 8 . In all cases the reaction was slower than that without $\mathrm{Mg}^{2+}$, and the reaction rate drop has an inverse linear relationship with the increase of $\mathrm{Mg}^{2+}$ (Figure 5). According to these results the concentration of $\mathrm{Mg}^{2+}$ showed a significant inhibition effect on the reaction rate of glycerol.

Table 8. Reaction rate of the Fenton reaction of glycerol with a different $\mathrm{Mg}^{2+} / \mathrm{Fe}^{2+}$ ratio

\begin{tabular}{|c|c|c|}
\hline $\mathbf{M g}^{2+} \mathbf{\times 1 0 ^ { - 3 }} \mathbf{M}$ & $\mathbf{M g}^{2+} / \mathbf{F e}^{2+}$ & $\mathbf{k}_{1}(\mathbf{1} / \mathbf{s})$ \\
\hline 0 & 0 & $2.3 \pm 0.1 \times 10^{-3}$ \\
\hline 2 & 1 & $1.9 \pm 0.1 \times 10^{-3}$ \\
\hline 4 & 2 & $1.3 \pm 0.1 \times 10^{-3}$ \\
\hline 6 & 3 & $0.9 \pm 0.1 \times 10^{-3}$ \\
\hline 8 & 4 & $0.6 \pm 0.1 \times 10^{-3}$ \\
\hline
\end{tabular}

$$
\begin{gathered}
\text { Vol }=50 \mathrm{ml} ; \mathrm{T}=21.0 \pm 0.1^{\circ} \mathrm{C} ; \mathrm{Fe}^{2+}=2.0 \pm 0.1 \times 10^{-3} \mathrm{M} ; \\
\mathrm{H}_{2} \mathrm{O}_{2}=2.0 \pm 0.1 \times 10^{-2} \mathrm{M} ; \mathrm{pH}=2.5 \pm 0.1 ; \text { glycerol }=2.0 \pm 0.1 \times 10^{-2} \mathrm{M}
\end{gathered}
$$

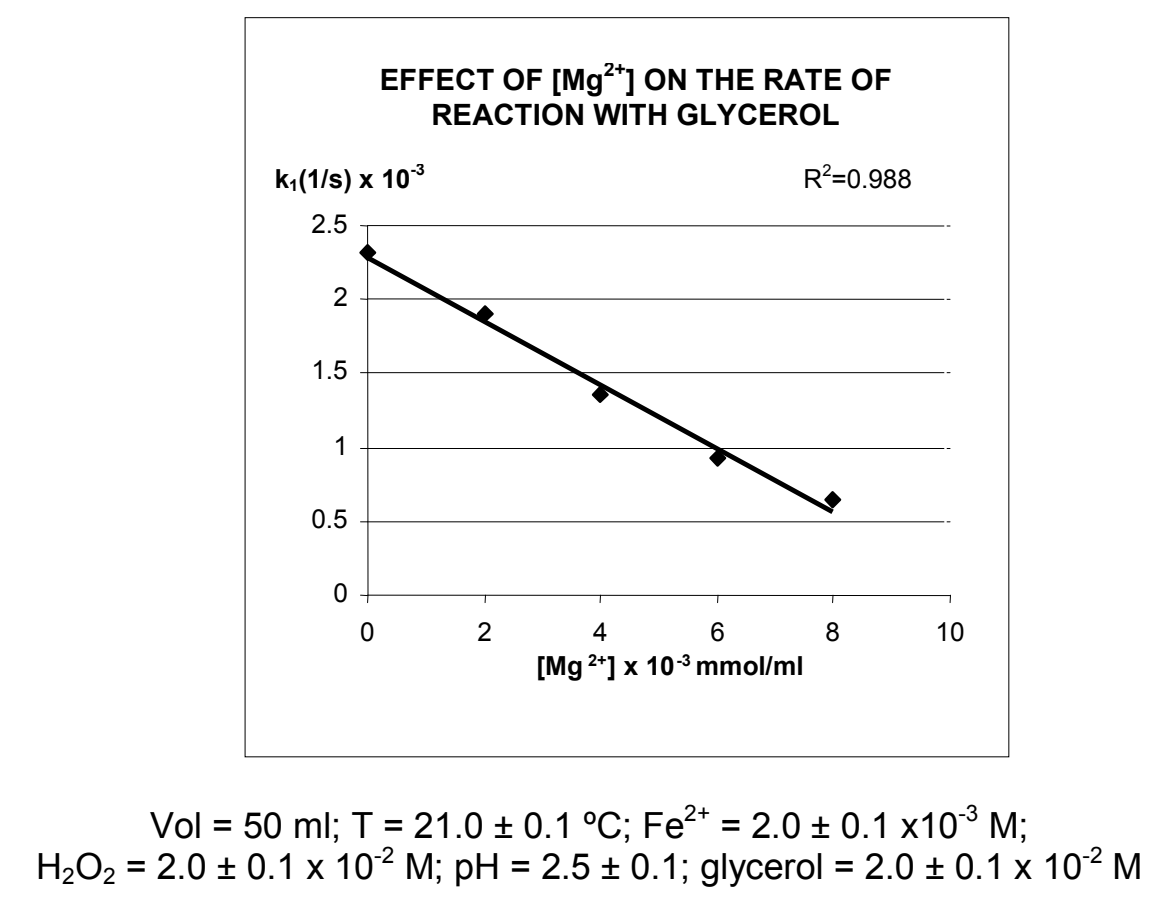

Figure 5. Effect of $\mathrm{Mg}^{2+}$ in the rate of the Fenton reaction with glycerol 


\section{Summary of the results of the study of the Fenton reaction with glycerol, and considerations about the mechanism}

1.- According to experimental results, the amount of $\mathrm{H}_{2} \mathrm{O}_{2}$ consumed in the absence of air is higher than in the presence of air (Table 1). Therefore, 1 mol of glycerol $\left(\mathrm{C}_{3} \mathrm{H}_{8} \mathrm{O}_{3}\right)$ needs 4.1 mols of $\mathrm{H}_{2} \mathrm{O}_{2}$ with air, and 7.3 mols of $\mathrm{H}_{2} \mathrm{O}_{2}$ without air for full oxidation to $\mathrm{CO}_{2}$ and $\mathrm{H}_{2} \mathrm{O}$. This result was checked by independent COD test at the beginning and at the end of the reaction. It means that oxygen participates in the reaction, being very important for the elucidation of the mechanism.

According to the stoichiometry of the reaction for the full oxidation of glycerol, if $\mathrm{H}_{2} \mathrm{O}_{2}$ is the only source of oxygen, theoretically 7 mols of $\mathrm{H}_{2} \mathrm{O}_{2}$ are necessary to complete the oxidation of $1 \mathrm{~mol}$ of glycerol to $\mathrm{H}_{2} \mathrm{O}$ and $\mathrm{CO}_{2}$. This fact can be explained by reactions (4), (5), and (6).

$$
\begin{aligned}
\mathrm{C}_{3} \mathrm{H}_{8} \mathrm{O}_{3}+4 \mathrm{H}_{2} \mathrm{O}_{2} & \longrightarrow 3 \mathrm{CO}_{2}+5 \mathrm{H}_{2} \mathrm{O}+6 \mathrm{H}^{+}+6 \mathrm{e}^{-} \\
3 \mathrm{H}_{2} \mathrm{O}_{2}+6 \mathrm{H}^{+}+6 \mathrm{e}^{-} & \longrightarrow 6 \mathrm{H}_{2} \mathrm{O} \\
\mathrm{C}_{3} \mathrm{H}_{8} \mathrm{O}_{3}+7 \mathrm{H}_{2} \mathrm{O}_{2} & \longrightarrow 3 \mathrm{CO}_{2}+11 \mathrm{H}_{2} \mathrm{O}
\end{aligned}
$$

In the presence of oxygen, 4 mols of $\mathrm{H}_{2} \mathrm{O}_{2}$ (experimentally, 4.1 mols; Table 1) are necessary for complete oxidation of $1 \mathrm{~mol}$ of glycerol. It means that oxygen dissolved in water participates as oxidant in the Fenton reaction, which is possible because the redox potential of oxygen in water at $\mathrm{pH} 2.0$ is high enough $\left(1.002 \mathrm{~V}\right.$ at $20^{\circ} \mathrm{C}$ and 0.21 bar $)$ for being a good electron scavenger. Reactions (7), (8) and (9).

$$
\begin{aligned}
\mathrm{C}_{3} \mathrm{H}_{8} \mathrm{O}_{3}+4 \mathrm{H}_{2} \mathrm{O}_{2} & \longrightarrow 3 \mathrm{CO}_{2}+5 \mathrm{H}_{2} \mathrm{O}+6 \mathrm{H}^{+}+6 \mathrm{e}^{-} \\
1.5 \mathrm{O}_{2}+6 \mathrm{H}^{+}+6 \mathrm{e}^{-} & \longrightarrow 3 \mathrm{H}_{2} \mathrm{O} \\
\mathrm{C}_{3} \mathrm{H}_{8} \mathrm{O}_{3}+4 \mathrm{H}_{2} \mathrm{O}_{2}+1.5 \mathrm{O}_{2} & \longrightarrow 3 \mathrm{CO}_{2}+8 \mathrm{H}_{2} \mathrm{O}
\end{aligned}
$$


2.- If the order of addition is changed, and to an iron solution in water at an adjusted $\mathrm{pH}$ $(1.8<\mathrm{pH}<2.6)$, a solution of glycerol and hydrogen peroxide is added, iron hydroxides precipitate, and the reaction does not take place. This happens only with glycerol. However, if the acid solution of glycerol is prepared at $20^{\circ} \mathrm{C} 20 \mathrm{~min}$ before adding iron, the reaction can be performed normally. This result means that it is necessary to reach the equilibrium between glycerol 1 and its dehydrated derivative (enol) 2, in which the $n$ electron pair of oxygen increases the electron density of the alkene. This is the necessary ligand $\mathbf{2}$ to keep $\mathrm{Fe}^{2+}$ in solution for catalytic purposes. It is important to achieve enough concentration of $\mathbf{2}$ to produce the iron complex $\mathbf{5}$ that is needed as catalyst of the reaction (Figure 6). This effect cannot be observed with other compounds of Table 2 because this step is too fast. The possible formation of hydroxyalkene derivatives has been previously reported by Ingles. ${ }^{17}$

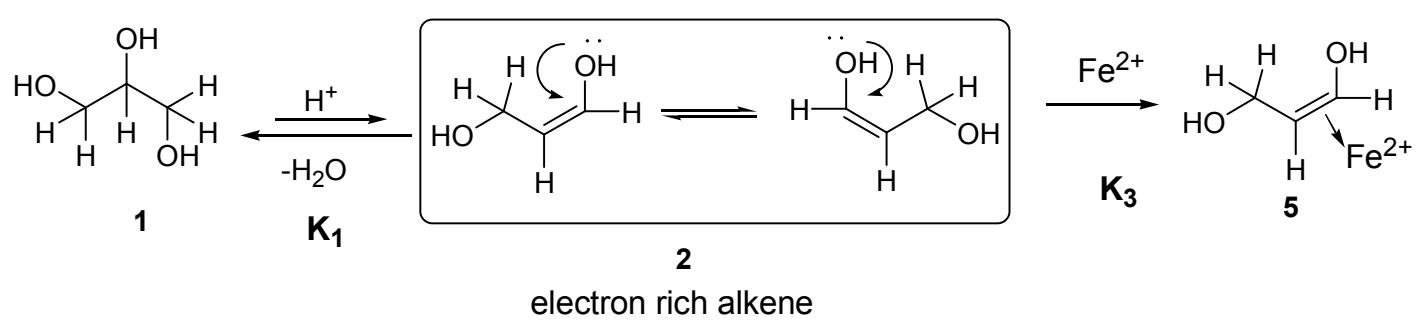

Figure 6. Partial dehydration of glycerol in acid media to produce ligand $\mathbf{2}$ and complex $\mathbf{5}$

3.- The reaction does not take place at $\mathrm{pH}<1.8$. Moreover, it is necessary to start the reaction at $\mathrm{pH}<2.6$ to avoid the precipitation of iron hydroxides. This result shows the relevance of $\mathrm{pH}$ control. At a lower $\mathrm{pH}$ the reaction is slower than at a higher $\mathrm{pH}$. We attributed this effect to the protonation of the enol to produce compound $\mathbf{4}$ (Figure $\mathbf{7}$ ), in which the electron density of the alkene is diminished, so that concentration of 2 decreases with the consequent lowering of the concentration of 5 that is in the ratedetermining step of the reaction. 


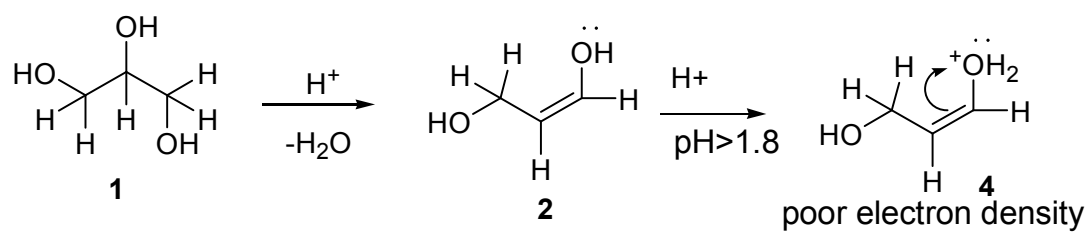

Figure 7. Protonation of $\mathbf{2}$ to produce the electron-poor compound $\mathbf{4}$

The concentration of $\mathrm{H}_{2} \mathrm{O}_{2}$ has no effect on the rate of the reaction (Figure 3), thus meaning that the $\mathrm{H}_{2} \mathrm{O}_{2}$ addition step is too fast compared with other steps of the mechanism.

4.- The inhibition effect of $\mathrm{Mg}^{2+}$ on the reaction rate was studied, showing that the decreasing of the reaction rate keeps a linear relationship with the increasing of $\mathrm{Mg}^{2+}$ concentration (Table 8). Therefore, $\mathrm{Mg}^{2+}$ participates in the reaction mechanism similar as $\mathrm{H}^{+}$as described above. $\mathrm{Mg}^{2+}$ reacts with the electron pair of the oxygen in the enol moiety, producing compound $\mathbf{3}$ (Figure $\mathbf{8}$ ) with the consequent decreasing of ligand $\mathbf{2}$, and catalyst 5. The role of carbohydrates in complex formation with magnesium was previously reported in literature. ${ }^{31,32}$
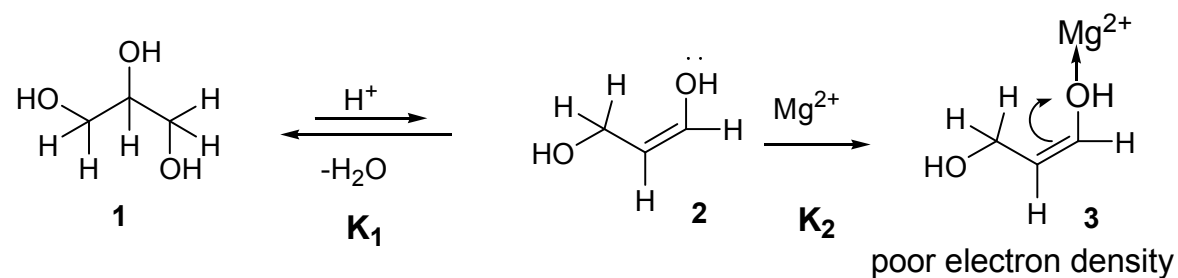

Figure 8. Proposed structure 3 for the reaction of $\mathrm{Mg}^{2+}$ with 2.

5.- The reaction started with $\mathrm{Fe}^{3+}$ as the only source of iron is too much slower than that started with the same concentration of $\mathrm{Fe}^{2+}$ (Table 6), but according to the Arrhenius plot $\mathrm{E}_{\mathrm{a}}$ is the same for both $\mathrm{Fe}^{2+}$ and $\mathrm{Fe}^{3+}$ reactions (Table 6; Figure 4). At the end of the reaction only $\mathrm{Fe}^{2+}$ was found at the same concentration as the initial concentration of $\mathrm{Fe}^{3+}$ (Table 5), which means than $\mathrm{Fe}^{3+}$ had to be reduced to $\mathrm{Fe}^{2+}$ by $\mathrm{H}_{2} \mathrm{O}_{2}$ before the reaction begins, as shown in (10), (11) and (12). This is the reason for a too much slower reaction with $\mathrm{Fe}^{3+}$ than with $\mathrm{Fe}^{2+}$. As the activation energy for both $\mathrm{Fe}^{2+}$ and $\mathrm{Fe}^{3+}$ reactions is the 
same, then the difference in the reaction rate depends on the initial $\mathrm{Fe}^{2+}$ concentration. In fact, $\mathrm{Fe}^{2+}$ is the only iron ion species that takes place in the Fenton reaction.

Therefore, starting with $\mathrm{Fe}^{3+}$, the reaction is slow because at the beginning there is small amount of $\mathrm{Fe}^{2+}$ produced by the reduction of $\mathrm{Fe}^{3+}$. The reaction rate increases as the concentration of $\mathrm{Fe}^{2+}$ increases. Moreover, the reaction is slower with $\mathrm{Fe}^{3+}$ than with $\mathrm{Fe}^{2+}$ not for occurring another mechanism, but for the low concentration of $\mathrm{Fe}^{2+}$.

$$
\begin{aligned}
& 2 \mathrm{Fe}^{3+}+2 \mathrm{e}^{-} \longrightarrow 2 \mathrm{Fe}^{2+}+0.77 \mathrm{mV} \\
& \mathrm{H}_{2} \mathrm{O}_{2} \longrightarrow \mathrm{O}_{2}+2 \mathrm{H}+6 \mathrm{e}--0.68 \mathrm{mV} \\
& 2 \mathrm{Fe}^{3+}+\mathrm{H}_{2} \mathrm{O}_{2} \longrightarrow 2 \mathrm{Fe}^{2+}+\mathrm{O}_{2}+0.11 \mathrm{mV}
\end{aligned}
$$

6.- The $\mathrm{H}^{+}$concentration increases ( $\mathrm{pH}$ decreases) along the reaction, and when it is over, it becomes stable (Figure 2), and bubbles begin to appear. Reaction (13). The $\mathrm{H}^{+}$ concentration increasing is resumed when more $\mathrm{H}_{2} \mathrm{O}_{2}$ is added. This $\mathrm{pH}$ variation is usually not observed when carrying out the reaction in buffers. We point out that this $\mathrm{pH}$ decrease is due to products like $\mathrm{H}_{2} \mathrm{CO}_{3}$ and $\mathrm{CO}_{2}$ that produce bubbles when the $\mathrm{pH}$ is too low to reach the solubility equilibrium of gaseous $\mathrm{CO}_{2}$ in water. Reactions (13), (14), and (15).

$$
\begin{aligned}
\mathrm{CO}_{2}(\mathrm{aq}) & \longrightarrow \mathrm{CO}_{2}(\mathrm{~g}) \text { (bubbles) } \\
\mathrm{CO}_{2}+\mathrm{H}_{2} \mathrm{O} & \longrightarrow \mathrm{H}_{2} \mathrm{CO}_{3} \\
\mathrm{H}_{2} \mathrm{CO}_{3} & \longrightarrow \mathrm{HCO}_{3}^{-}+\mathrm{H}^{+} \text {(pH decreases) }
\end{aligned}
$$

7.- The reaction takes place with glycerol and other polyols like mannitol, and carbohydrates like glucose, sucrose, and others. The presence of the 1,2,3-triol moiety is necessary for carrying out the reaction, as also reported by Ingles. ${ }^{17}$ We propose that it is due to the formation of an electron-rich enediol structure 2 that reacts with $\mathrm{Fe}^{2+}$ to produce a catalyst complex $\mathbf{5}$ that is the only intermediate responsible for the reaction rate. 
We have also found that methanol and ethanol do not react under these reaction conditions due to the impossibility of enol formation.

\section{Discussion about the mechanism}

According to these results we propose the mechanism of SCHEME 1

Step 1: Dehydration of glycerol 1 to form the enediol 2.

The kinetics of dehydration of glycerol at room temperature has been scarcely studied.

There are reports on glycerol dehydration under extreme conditions, at high temperatures and very acid media. This fact has been mentioned by Nimlos et al., ${ }^{33}$ who explained the mechanisms of glycerol dehydration in acid media and calculated the activation energy of reaction that is $20-25 \mathrm{kcal} / \mathrm{mol}$.

This is a high activation energy for this endothermic reaction of protonated glycerol, thus implying that the concentration of the dehydration product is too low at room temperature.

The $\mathrm{H}^{+}$concentration is critical in this step. A low $\mathrm{pH}$ is important to yield the enediol 2. ${ }^{25}$ However, pH cannot be too low (below 1.8) because the reaction does not start, (Figure 7) and it cannot be too high (over 2.8) because iron hydroxides begin to precipitate. In the case of glycerol the formation of the enediol is slow, therefore, it is necessary some time to produce the required amount of enediol to form the complex $\mathbf{5}$ with $\mathrm{Fe}^{2+}$. With other polyols like mannitol or glucose, this step is too much faster under these reaction conditions, as several enediol structures can be produced.

Step 2: Formation of the catalytic complex 5

Taking into account the huge bibliography about the use of the Fenton reaction for degradation of organic compounds, many of them have common structural properties. They are alkenes or aromatics with electron-rich or electron donor properties that can 
produce a square planar complex with $\mathrm{Fe}^{2+}$ like 5 . This structure is necessary for two purposes, (a) to keep $\mathrm{Fe}^{2+}$ in solution to avoid iron hydroxides precipitation, and (b) to produce a catalytic core to activate the organic compound for Fenton oxidation. (This is a structural requirement like in the hemo moiety in biological systems that have a square planar complex with a $\mathrm{Fe}^{2+}$ core to carry oxygen).

According to the results shown in Table 4, the reaction rate increases linearly with the increasing of the iron concentration, so $\mathrm{Fe}^{2+}$ concentration is in the rate-determining step of the reaction, and as it is in the core of the catalytic complex $\mathbf{5}$, the reaction rate is directly related with the concentration of it, as shown in (18), and (19), which only depends on the concentration of $\mathrm{Fe}^{2+}$, and hydroxy alkene 2. Reactions (16) and (17).

$$
\begin{aligned}
\mathrm{K}_{3} & =[5] /\left(\left[\mathrm{Fe}^{2+}\right][2]\right) \\
{[5] } & =\mathrm{K}_{3}\left[\mathrm{Fe}^{2+}\right][2] \\
\Delta\left[\mathrm{H}_{2} \mathrm{O}_{2}\right] / \Delta \mathrm{t} & =\mathrm{k}_{1}[5] \\
\mathrm{d}\left[\mathrm{H}_{2} \mathrm{O}_{2}\right] / \mathrm{dt} & =\mathrm{k}_{1} \mathrm{~K}_{3}\left[\mathrm{Fe}^{2+}\right][2]
\end{aligned}
$$

\section{Inhibition by $\mathrm{Mg}^{2+}$}

When $\mathrm{Mg}^{2+}$ is added, the reaction rate decreases linearly with the concentration of $\mathrm{Mg}^{2+}$ (Table 8). The whole effect is that the amount of complex 5 decreases proportionally with $\mathrm{Mg}^{2+}$ increasing. Reactions (20), (21), (22), and (23).

$$
\begin{array}{lc}
\mathrm{K}_{2}= & {[3] /\left[\mathrm{Mg}^{2+}\right][2]} \\
{[3]=} & \mathrm{K}_{2}\left[\mathrm{Mg}^{2+}\right][2] \\
{[5]=} & {[2] \mathrm{K}_{3}\left[\mathrm{Fe}^{2+}\right]-[2] \mathrm{K}_{2}\left[\mathrm{Mg}^{2+}\right]} \\
{[5]=} & {[2]\left(\mathrm{K}_{3}\left[\mathrm{Fe}^{2+}\right]-\mathrm{K}_{2}\left[\mathrm{Mg}^{2+}\right]\right)}
\end{array}
$$

This effect can be observed with glycerol because the concentration of $\mathbf{2}$ seems to be very low. However, it is more difficult to be observed with other polyols or other compounds, in which the concentration of intermediates like $\mathbf{2}$ are higher, thus being 
necessary to increase too much $\mathrm{Mg}^{2+}$ concentration to get a measurable effect on the reaction rate.

Step 3: Reaction of 5 with $\mathrm{H}_{2} \mathrm{O}_{2}$

In this step $\mathrm{H}_{2} \mathrm{O}_{2}$ reacts with 5 to produce complex $\mathbf{6}$, in which oxygen is in singlet state. Sugimoto and Sawyer ${ }^{10}$ previously reported the reaction products of several organic substrates like diphenylisobenzofuran and 9,10-diphenylantracene, in which they found oxygenated products that are consistent with a singlet oxygen intermediate in acetonitrile. This important fact was barely mentioned by authors of papers and reviews about the mechanism of the Fenton reaction. The driving force is given by the formation of a singlet oxygen complex that can react very fast with the organic ligand, being present in the coordination sphere of the complex. Here, we report our results under these reaction conditions with these substrates occurring through a singlet oxygen mechanism, in a pHdependent reaction. Therefore, we propose that singlet oxygen is formed in the first step of the reaction of $\mathrm{H}_{2} \mathrm{O}_{2}$ with $\mathrm{Fe}^{2+}$ complex, which is in agreement with the structural and electronic requirements for the formation of a singlet dioxygen complex, as it is mentioned in literature. ${ }^{34}$

The spectroscopic evidence that we have is the absorbance at $460 \mathrm{~nm}$ that appears after adding $\mathrm{H}_{2} \mathrm{O}_{2}$ to the reaction mixture, and disappears when $\mathrm{H}_{2} \mathrm{O}_{2}$ is exhausted. This absorbance value is close to those of hemoprotein models of ferrous porphyrins with oxygen according to literature. ${ }^{35,36}$

Also there is important bibliography about the structural requirements of $\mathrm{Fe}^{2+}$ complexes for carrying oxygen in a reversible way. ${ }^{34,37,38}$ 

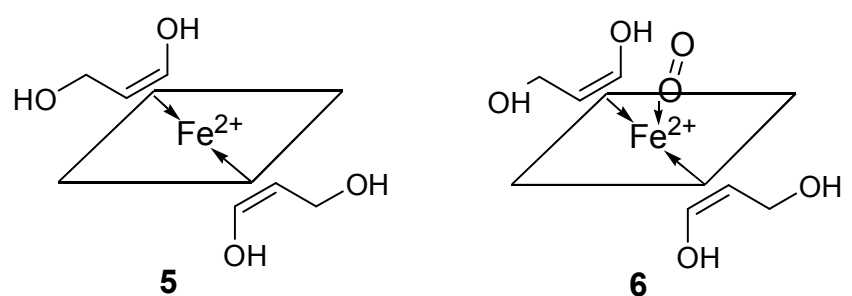

Figure 9. Proposed structures of complexes $\mathbf{5}$ and $\mathbf{6}$.

Step 4: Intramolecular reaction of singlet oxygen with ligands.

Singlet $\mathrm{O}_{2}$ is a very reactive compound, ${ }^{36}$ so that it can react in an intramolecular way with the activated substrate in the same coordination sphere, producing intermediate complex 7, which can give rise to carbonyl compounds by ${ }^{1} \mathrm{O}_{2} 2+2$ cycloaddition reactions, ${ }^{39,40,41,42}$ and $\mathrm{CO}_{2}$ when it is fully oxidized.

Step 5: Recycling of $\mathrm{Fe}^{2+}$.

These partially oxidized compounds can leave de coordination sphere of the complex to produce intermediate oxidized compounds like $12,13,14$, and 15 , and leave $\mathrm{Fe}^{2+}$ to react either with another ligand $\mathbf{2}$ to regenerate complex $\mathbf{5}$ or with partially oxidized products like 14 to produce other complexes like 9 until yielding $\mathrm{CO}_{2}$.

This ketene 14 is a long-lived intermediate because of forming an iron(II)-ketene complex such as that previously reported..$^{43}$

The iron(II)-ketene complex reacts with singlet oxygen giving an unstable dioxietane intermediate, which finally yields $\mathrm{CO}_{2}$ and water.

Step 6: Decreasing of $\mathrm{pH}$ due to the production of carbonic acid.

\section{Participation of $\mathrm{O}_{2}$ in the mechanism}

The participation of $\mathrm{O}_{2}$ as electron scavenger is shown in this paper. When during the course of the reaction $\mathrm{H}_{2} \mathrm{O}_{2}$ is in shortage compared with substrate like in stoichiometric studies (see experimental), in which $\mathrm{H}_{2} \mathrm{O}_{2}$ is added dropwise, the final oxidation of 
intermediates such as formaldehyde $15\left(E_{\text {red }}=-0.48 \mathrm{~V}\right)$ and formic acid $16\left(E_{\text {red }}=-0.61\right.$ $\mathrm{V})$ to $\mathrm{CO}_{2}$ is carried out by $\mathrm{O}_{2}$ dissolved in water $\left(\mathrm{E}_{\mathrm{red}}=+1.10 \mathrm{~V}\right.$ at $\mathrm{pH} 3$ and $p_{\mathrm{O} 2}=0.21$ bar) that is at constant concentration throughout the reaction. Therefore, when there is not enough $\mathrm{H}_{2} \mathrm{O}_{2}$ to perform the full oxidation to $\mathrm{CO}_{2}$, the first step is the addition to alkene to give dioxietane intermediates 10 and 12 before oxidizing 15 and 16 to $\mathrm{CO}_{2}$, and these intermediates are further oxidized by the $\mathrm{O}_{2}$ dissolved in water.

If the same reaction is carried without $\mathrm{H}_{2} \mathrm{O}_{2}$ in the presence of air, the only products will be those of oxidized iron. In this case, initial and final CODs are the same (Table 1, footnote). If some $\mathrm{O}_{2}$ radicals were produced from the air in the absence of $\mathrm{H}_{2} \mathrm{O}_{2}$, these radicals would be used for the irreversible oxidation of $\mathrm{Fe}^{2+}$, but not to perform the oxidation of the organic compounds.

Moreover, if a free radical participated in the absence of $\mathrm{H}_{2} \mathrm{O}_{2}$, some COD decrease related to the formation of oxidation products would be detected.

\section{ORP of the reaction media}

The redox potential of the solution that is measured by the ORP electrode can be explained by the ratio $\mathbf{6}$ (formally oxidized intermediate) / 5 (formally reduced intermediate) (Scheme 1).

(1) Before adding $\mathrm{H}_{2} \mathrm{O}_{2}, 5$ is the single reduced complex in the reaction media (point $\mathbf{A}$ in Figure 1).

(2) When $\mathrm{H}_{2} \mathrm{O}_{2}$ is added, the oxidized complex 6 appears, and the ratio $6 / 5$ increases until reaching a maximum, so the ORP increases (points $\mathbf{A}$ to $\mathbf{B}$ in Figure 1).

(3) When enough 6 is produced, the reaction begins and the ratio $6 / 5$ is kept constant while $\mathrm{H}_{2} \mathrm{O}_{2}$ is present, so the ORP remains constant (points $\mathbf{B}$ to $\mathbf{C}$ in Figure 1).

(4) When all $\mathrm{H}_{2} \mathrm{O}_{2}$ is consumed, 6 begins to decrease, so the ratio $\mathbf{6 / 5}$ decreases, and the ORP decreases until reaching a minimum (points $\mathbf{C}$ to $\mathbf{E}$ in Figure 1). 
(5) At this point more $\mathrm{H}_{2} \mathrm{O}_{2}$ can be added, if still there is enough substrate, ORP increases, and the reaction begins again. When there is not enough substrate, iron is oxidized, and iron hydroxides precipitate appears. Reactions (24), (25), and (26).

$$
\begin{aligned}
& 2 \mathrm{Fe}^{2+}+\mathrm{H}_{2} \mathrm{O}_{2}+2 \mathrm{H}^{+} \longrightarrow 2 \mathrm{Fe}^{3+}+2 \mathrm{H}_{2} \mathrm{O} \\
& 2 \mathrm{Fe}^{3+}+6 \mathrm{H}_{2} \mathrm{O} \longrightarrow 2 \mathrm{Fe}(\mathrm{OH})_{3} \text { (ppte.) }+6 \mathrm{H}^{+} \\
& 2 \mathrm{Fe}^{3+}+\mathrm{H}_{2} \mathrm{O}_{2} \longrightarrow 2 \mathrm{Fe}^{2+}+\mathrm{O}_{2}
\end{aligned}
$$


SCHEME 1: Mechanism of the Fenton reaction with glycerol, effect of oxygen and $\mathrm{Mg}^{2+}$

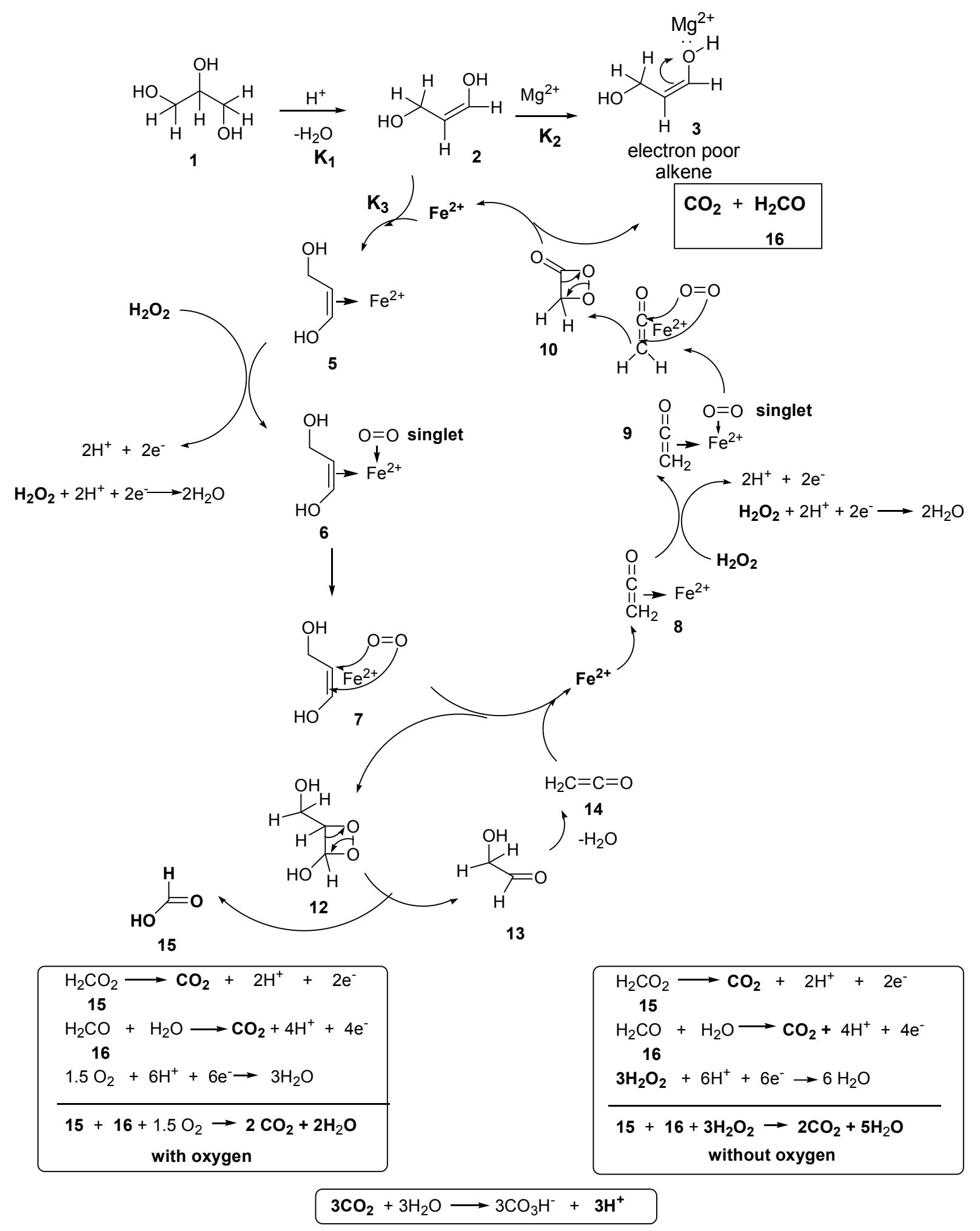




\section{Reaction of other substrates}

A similar set of reactions can be proposed to explain the stoichiometry of the other compounds of Table 1, reactions (27) - (34), that now can be compared with theoretical calculations (Table 9).

All results are in agreement with theoretical calculations of $\mathrm{H}_{2} \mathrm{O}_{2}$ consumption. This can be a useful tool to calculate the expense of $\mathrm{H}_{2} \mathrm{O}_{2}$ if the composition of a waste is roughly known, like in factories, in which sugar is the main raw material.

\begin{tabular}{|c|c|c|c|}
\hline $\begin{array}{l}\text { Sucrose } \\
\text { Lactose }\end{array}$ & $\begin{array}{l}\text { Without } \mathrm{O}_{2} \\
\text { With } \mathrm{O}_{2}\end{array}$ & $\begin{array}{r}\mathrm{C}_{12} \mathrm{H}_{22} \mathrm{O}_{11}+24 \mathrm{H}_{2} \mathrm{O}_{2} \\
\mathrm{C}_{12} \mathrm{H}_{22} \mathrm{O}_{11}+\mathbf{1 2} \mathrm{H}_{2} \mathrm{O}_{2}+6 \mathrm{O}_{2}\end{array}$ & $\begin{array}{l}12 \mathrm{CO}_{2}+35 \mathrm{H}_{2} \mathrm{O} \\
12 \mathrm{CO}_{2}+23 \mathrm{H}_{2} \mathrm{O}\end{array}$ \\
\hline $\begin{array}{l}\text { Glucose } \\
\text { Fructose }\end{array}$ & $\begin{array}{l}\text { Without } \mathrm{O}_{2} \\
\text { With } \mathrm{O}_{2}\end{array}$ & $\begin{array}{r}\mathrm{C}_{6} \mathrm{H}_{12} \mathrm{O}_{6}+12 \mathrm{H}_{2} \mathrm{O}_{2} \\
\mathrm{C}_{6} \mathrm{H}_{12} \mathrm{O}_{6}+6 \mathrm{H}_{2} \mathrm{O}_{2}+3 \mathrm{O}_{2}\end{array}$ & $\begin{array}{l}6 \mathrm{CO}_{2}+18 \mathrm{H}_{2} \mathrm{O} \\
6 \mathrm{CO}_{2}+12 \mathrm{H}_{2} \mathrm{O}\end{array}$ \\
\hline Mannitol & $\begin{array}{l}\text { Without } \mathrm{O}_{2} \\
\text { With } \mathrm{O}_{2}\end{array}$ & 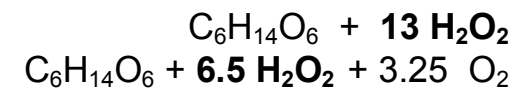 & $\begin{array}{l}6 \mathrm{CO}_{2}+20 \mathrm{H}_{2} \mathrm{O} \\
6 \mathrm{CO}_{2}+13.5 \mathrm{H}_{2} \mathrm{O}\end{array}$ \\
\hline $\begin{array}{l}\text { Tartaric } \\
\text { Acid }\end{array}$ & $\begin{array}{l}\text { Without } \mathrm{O}_{2} \\
\text { With } \mathrm{O}_{2}\end{array}$ & $\begin{array}{r}\mathrm{C}_{4} \mathrm{H}_{6} \mathrm{O}_{6}+5 \mathrm{H}_{2} \mathrm{O}_{2} \\
\mathrm{C}_{4} \mathrm{H}_{6} \mathrm{O}_{6}+3 \mathrm{H}_{2} \mathrm{O}_{2}+\mathrm{O}_{2}\end{array}$ & $\begin{array}{l}4 \mathrm{CO}_{2}+8 \mathrm{H}_{2} \mathrm{O} \\
4 \mathrm{CO}_{2}+6 \mathrm{H}_{2} \mathrm{O}\end{array}$ \\
\hline
\end{tabular}

Table 9. Complete intake of $\mathrm{H}_{2} \mathrm{O}_{2}$ with and without $\mathrm{O}_{2}$, and comparison with theoretical calculations

\begin{tabular}{|c|c|c|c|c|}
\hline (S) & \multicolumn{2}{|c|}{ A } & \multicolumn{2}{c|}{ B } \\
\hline & Exper. & Calc. & Exper. & Calc. \\
\hline Gly & $4.1 \pm 0.1$ & 4 & $7.3 \pm 0.1$ & 7 \\
\hline Suc & $11.7 \pm 0.1$ & 12 & $24.8 \pm 0.1$ & 24 \\
\hline Man & $6.7 \pm 0.1$ & 6.5 & $13.2 \pm 0.1$ & 13 \\
\hline Lac & $11.5 \pm 0.1$ & 12 & $24.3 \pm 0.1$ & 24 \\
\hline Glu & $6.0 \pm 0.1$ & 6 & $12.5 \pm 0.1$ & 12 \\
\hline Fru & $6.0 \pm 0.1$ & 6 & $12.3 \pm 0.1$ & 12 \\
\hline Tar & $3.1 \pm 0.1$ & 4 & $5.2 \pm 0.1$ & 5 \\
\hline
\end{tabular}

Concentration of the substrate $(\mathbf{S})=2.0 \pm 0.1 \mathrm{mg} / \mathrm{ml} ; \mathrm{Fe}^{2+}=1.5 \pm 0.1 \times 10^{-3} \mathrm{M} ; \mathrm{T} 20^{\circ} \mathrm{C} ; \mathrm{pH} 2.5 \pm$ 0.1. $\mathbf{C D O}=\mathrm{mg} \mathrm{O}_{2} / \mathrm{l}$. $\mathbf{A}=\mathrm{mmol} \mathrm{H}_{2} \mathrm{O}_{2} / \mathrm{mmol} \mathrm{S}$ (with $\mathrm{O}_{2}$ ); $\mathbf{B}=\mathrm{mmol} \mathrm{H}_{2} \mathrm{O}_{2} / \mathrm{mmol} \mathrm{S}$ (without $\mathrm{O}_{2}$ ). Gly (Glycerol); Suc (Sucrose); Man (Mannitol); Lac (Lactose); Glu (Glucose); Fru (Fructose); Tar (Tartaric Acid). Exper. $=$ Experimental; Calc. (calculated). 


\section{Comparative rates of reaction}

The reaction rate depends on the concentrations of iron and hydroxyalkene type-2 (Figure 6; reactions 16-19) as demonstrated for glycerol. So, at a constant iron concentration the greater concentration of hydroxyalkene type-2 there is, the higher the rate of reaction (Figure 6).

The concentration of the hydroxyalkene type-2 further depends on the capacity of formation of this alkene described as $\mathbf{K}_{\mathbf{1}}$. (35) and (36).

$$
\begin{aligned}
\mathrm{K}_{1}= & {[2] /[1] } \\
{[2]=} & {\left[\mathrm{K}_{1}\right][1] }
\end{aligned}
$$

Upon comparison of polyhydroxy compounds such as mannitol and glycerol, mannitol contains four secondary $\mathrm{HO}$, while glycerol have one, therefore, mannitol will render higher hydroxyalkene type-2 concentration than glycerol $\left(\mathbf{K}_{1 \text { man }}>\mathbf{K}_{1}\right.$ gly $)$. Then, the rate of reaction of mannitol will be greater than that of glycerol.

Fructose and glucose are both hexoses, but fructose is a ketose, then it contains a carbonyl group at C-2, which migrates in acid media, so readily stabilized hydroxyalkenes can be formed by dehydration $(\Delta \mathrm{G}=-25,6 \mathrm{kcal} / \mathrm{mol}) .{ }^{44}$ Therefore, the hydroxyalkene concentration is higher for fructose than mannitol ( $\left.\mathbf{K}_{\mathbf{1} \text { fru }}>\mathbf{K}_{\mathbf{1} \text { man }}\right)$, and also the rate of reaction.

Glucose has one aldehydic carbonyl group, but first isomerizes to fructose in acid media with an endothermic barrier of $\Delta \mathrm{G}=+1.53 \mathrm{kcal} / \mathrm{mol},{ }^{44}$ which makes $\mathbf{K}_{1}$ glu $<\mathbf{K}_{1}$ fru. Therefore, the rate of reaction is slower for glucose than fructose. In the case of the disaccharide sucrose, since both anomeric carbons are involved in the interglycosidic bond, a previous hydrolysis reaction step is required to obtain two monosaccharides. Therefore, the rate of reaction is minor than that of monosaccharides and polyhydroxy compounds. The other disaccharide lactose comprises only one anomeric carbon in the interglycosidic bond. Therefore, the rate of reaction is somewhat 
greater than that of sucrose and polyhydroxy compounds as mannitol, but minor than those of monosaccharides such as glucose.

In the case of tartaric acid the hydroxyalkene is conjugated with two carboxylic groups that make the hydroxyalkene production thermodynamically more favorable than those of carbohydrates (which have carbonyl groups), and any other compound of Table 2, so the reaction is the fastest of all them. According to these statements a scale of relative reactivities related to $\mathbf{K}_{1}$ can be proposed.

$$
\mathrm{K}_{1 \text { tar }}>\mathrm{K}_{1 \text { fru }}>\mathrm{K}_{1 \text { glu }}>\mathrm{K}_{1 \text { lac }}=\mathrm{K}_{1 \text { man }}>\mathrm{K}_{1 \text { suc }}>\mathrm{K}_{1 \text { gly }}
$$

This explanation is very important for getting a clue on the mechanism, because it is clear that the rate of reaction strongly depends on the structure of the substrate taking into account its ability to produce hydroxyalkene intermediates. The reaction is faster when more hydroxyalkene is produced.

If the reaction were via free radicals or ferryl mechanisms the structure of the substrate would have little or not influence in the reaction rate.

\section{CONCLUSIONS}

In this paper new mechanistic insights of the oxidation of carbohydrates by the Fenton reaction using glycerol as experimental model are described according to experimental results, showing the importance of ORP measures as an experimental tool to study this kind of reactions. We remark the use of glycerol as a model compound because the reaction is slow enough to reduce experimental error, and the use of independent methods as the dichromate reaction to check the exhaust of $\mathrm{H}_{2} \mathrm{O}_{2}$, and COD to measure the full consumption of the organic substrates. 
(1) Stoichiometry: It was carefully measured, and these results were of great importance for understanding the role of oxygen in the mechanism.

(2) Importance of oxygen: We disclosed and measured how oxygen participates in the Fenton reaction. In aerobic conditions it plays a key role in the mechanism, this is important in industrial operations as degradation of liquid waste by Fenton reaction, because with an energic aeration, significative amounts of $\mathrm{H}_{2} \mathrm{O}_{2}$ can be saved decreasing the cost of the process. Also it may have importance to explain some biological mechanisms.

(3) Oxidation state of Fe: Many authors indicate that the Fenton reaction can be carried out indistinctly with $\mathrm{Fe}^{2+}$ or $\mathrm{Fe}^{3+}$ with only some differences in the reaction rate, depending on the initial oxidation state of Fe. However, all mechanisms described up to now indicate that $\mathrm{Fe}^{3+}$ participates in the Fenton reaction. As far as we know this is the first time that experimental evidence is provided showing that $\mathrm{Fe}^{2+}$ is the only iron ion species that is involved in the Fenton reaction because it can produce the planar complex that is necessary for this kind of catalysis. When $\mathrm{Fe}^{3+}$ is used a previous reduction step to $\mathrm{Fe}^{2+}$ is required before the reaction starts. The difference in the reaction rate is due to accumulating enough $\mathrm{Fe}^{2+}$ upon reduction of $\mathrm{Fe}^{3+}$.

(4) Inhibitor effect of $\mathbf{M g}^{2+}$ : As far as we know this is the first time that the inhibitor effect of $\mathrm{Mg}^{2+}$ is reported in the Fenton reaction with a rational involvement in the mechanism. It is necessary to point out the great importance that this effect may have in biological and industrial processes because $\mathrm{Mg}^{2+}$ is a widely distributed cation that can be found elsewhere.

(5) Structure of the catalytic intermediate: We described the structural requirements that must fulfill the substrate to behave as a reactive ligand in the Fenton reaction in catalytic concentrations and room temperatures. They must be able to produce an electron-rich planar complex with $\mathrm{Fe}^{2+}$ to give rise to singlet oxygen after reacting with 
$\mathrm{H}_{2} \mathrm{O}_{2}$. This is the explanation of why not all organic compounds can be oxidized by the

Fenton reaction under mild reaction conditions.

Finally, in this paper a rational mechanism for the oxidation of glycerol using the Fenton

reaction is proposed. Further extension of this mechanism is currently under study.

\section{ACKNOWLEDGMENTS}

To CONICET, Universidad de Buenos Aires (Argentina), and Ministerio de Ciencia, Tecnología e Innovación Productiva (MINCYT, Argentina).

\section{REFERENCES}

(1) Fenton, H. J. H. LXXIII. - Oxidation of Tartaric Acid in Presence of Iron J. Chem. Soc. Trans. 1894, 65, 899 - 910.

(2) von Sonntag, C. Advanced Oxidation Processes: Mechanistics Aspects. Water Sci. Technol. 2008, 58, 5, $1015-1021$.

(3) Schönbein, C. F. Über die gegenseitige Katalyse einer Reihe von Oxyden, Superoxyden und Sauerstoffsaüren und die chemisch gegensätzlichen Zustände des in innen enthaltenen thätigen Sauerstoffes. J. prakt. Chem. 1857, 77, 129 - 149.

(4) Diyaudden, B. H.; Abdul Aziz, A. R.; Daud, W. M. A. W. On The Limitation of Fenton Oxidation Operational Parameters: A Review. R2. Int. J. Chem. React. Eng. 2012, 10, 1 25.

(5) Prousek, J. Fenton Chemistry in Biology and Medicine. Pure Appl. Chem. 2007, 79, 12, $2325-2338$.

(6) Haber, F.; Weiss, J. Über die Katalyse des hydroperoxydes. Naturwissenschaften 1932, 20, 948-950. Haber, F.; Weiss, J. The Catalytic Decomposition of Hydrogen Peroxide by Iron Salts. Proc. R. Soc. Lond. A 1934, 147, 332 - 352.

(7) Koppenol, W. H. The Haber-Weiss Cycle - 70 Years Later. Redox Report 2001, 6, 4, $229-234$.

(8) Bray, W. C.; Gorin, M. H. Ferryl Ion a Compound of Tetravalent Iron. J. Am. Chem. Soc. 1932, 54, $2124-2125$.

(9) Barb, W. G.; Baxendale, J. H.; George, P.; Hargrave, K. R. Reactions of Ferrous and Ferric lons with Hydrogen Peroxide. Part I.-The Ferrous Ion Reaction. Trans. Faraday Soc. 1951, 47, 462 - 500.

(10) Sugimoto, H.; Sawyer, D. T. Iron (II) - Induced Activation of Hydrogen Peroxide to Ferryl Ion $\left(\mathrm{FeO}^{2+}\right)$ and Singlet Oxygen $\left({ }^{1} \mathrm{O}_{2}\right)$ in Acetonitrile: Monoxygenations, Dehydrogenations and Dioxigenations of Organic Substrates. J. Am. Chem. Soc. 1984, $106,4283-4285$. 
(11) Rachmilovich - Calis, S.; Masarwa, A.; Meyerstein, N.; Meyerstein, D.; van Eldik, R. New Mechanistic Aspects of the Fenton Reaction. Chem. Eur. J. 2009, 15, 8303 - 8309.

(12) Kremer, M. L. Mechanism of the Fenton reaction. Evidence of a New Intermediate. Phys. Chem. Chem. Phys. 1999, 1, 3595 - 3605.

(13) Enamia, S.; Sakamoto, Y.; Colussi, A. J. Fenton Chemistry at Aqueous Interfaces. Proc. Nat. Acad. Sci. U.S.A. 2014, 111, 2, 623 - 628.

(14) Barbusinski, K. Fenton Reaction. Controversy Concerning the Chemistry. Ecol. Chem. Eng. 2009, 16, 3, 347 - 358.

(15) Pignatello, J. J.; Oliveros, E.; MacKay, A. Advanced Oxidation Processes for Organic Contaminant Destruction Based on the Fenton Reaction and Related Chemistry. Crit. Rev. Environ. Sci. Technol. 2006, 36, 1 - 84.

(16) Kornweitz; H.; Burg, A.; Meyerstein, D. Plausible Mechanisms of the Fenton-Like Reactions, $\mathrm{M}=\mathrm{Fe}(\mathrm{II})$ and $\mathrm{Co}(\mathrm{II})$, in the Presence of $\mathrm{RCO}_{2}{ }^{-}$Substrates: Are $\mathrm{OH} \cdot \mathrm{Radicals}$ Formed in the Process? J. Phys. Chem. A 2015, 119, $4200-4206$.

(17) Ingles, D. L. Studies of Oxidations by Fenton Reagents Using Redox Titrations II Effect of Oxygen. Aust. J. Chem. 1972, 25, 97 - 104.

(18) Utset, B.; Garcia, J.; Casado, J.; Domenech, X.; Peral, J. Replacement of $\mathrm{H}_{2} \mathrm{O}_{2}$ by $\mathrm{O}_{2}$ in Fenton and Photo-Fenton Reactions. Chemosphere 2000, 41, 1187 - 1192.

(19) Sawyer, D. T.; Sugimoto, H.; Calderwood, T. S. B. $\left(\mathrm{O}_{2}{ }^{--}\right.$, e- or $\left.\mathrm{OH}^{-}\right)$- Induced Autoxygenation of Organic Sustrate: A Model Chemical System for Cytochrome P - 450 Catalyzed Monoxygenation and Dehydrogenation by Dioxygen. Proc. Nat. Acad. Sci. U.S.A. 1984, 81, 8025 - 8027.

(20) Wang, H.-Y.; Hu, Y.-N.; Cao, G.-P.; Yuan, W.-K. Degradation of Propylene Glycol Wastewater by Fenton'S Reagent in a Semicontinuous Reactor. Chem. Eng. J. 2011, 170 $75-81$.

(21) Young-O, K.; Hai-Uk, N.; Yu-Ri, P.; Jong-Hyun, L.; Tae-Joo, P.; Tae-Ho, L. Fenton Oxidation Process Control Using Oxidation-reduction Potential Measurement for Pigment Wastewater Treatment. Korean J. Chem. Eng. 2004, 21(4), 801 - 805.

(22) Hermosilla, D.; Cortijo, M.; Huang, C. P. The Role of Iron on the Degradation and Mineralization of Organic Compounds Using Conventional Fenton and Photo - Fenton Processes. Chem. Eng. J. 2009,155, 637 - 646.

(23) Belcher, R. Application of Chelate Compounds in Analytical Chemistry. Pure Appl. Chem. 1973, 34, 13 - 27.

(24) Ingles, D. L. Studies of Oxidations by Fenton Reagents Using Redox Titrations I Oxidation of Some Organic Compounds. Aust. J. Chem. 1972, 25, 87 - 95.

(25) Ingles, D. L. Studies of Oxidations by Fenton Reagents Using Redox Titrations III Reactions with Carbohydrates and Polyhydroxy Compounds. Aust. J. Chem. 1972, 25, $105-108$. 
(26) Manini, P.; La Pietra, P.; Panzella, L.; Napolitano, A.; d'Ischia, M. Glyoxal Formation by Fenton-Induced Degradation of Carbohydrates and Related Compounds. Carbohydr. Res. 2006, 341, 1828 - 1833.

(27) Morelli, R.; Russo-Volpe, S.; Lo Scalzo, R. Fenton-Dependent Damage to Carbohydrates: Free Radical Scavenging Activity of Some Simple Sugars. J. Agric. Food Chem. 2003, 51, 7418 - 7425.

(28) Kremer, M. L. The Fenton Reaction. Dependence of the Rate on pH. J. Phys. Chem. A 2003, 107, 1734 - 1741.

(29) Cowan, J. A. Metallobiochemistry of Magnesium. Coordination Complexes with Biological Substrates: Site Specificity, Kinetics and Thermodynamics of Binding, and Implications for Activity. Inorg. Chem. 1991, 30, 13, 2741 - 2747.

(30) Hutchenson, R; Engemann, D; Cheng, I. F. A Hypothesis for the Basis of the ProOxidant Nature of Calcium lons. Biometals 2004, 17, 605 - 613.

(31) Angyal, S. J. Complexes of metal cations with carbohydrates in solution. Adv. Carbohydr. Res. 1989, 47, 1 - 43.

(32) Silva, D. J.; Kahne, D. E. Studies of the 2:I Chromomycin A3-Mg2+ Complex in Methanol: Role of the Carbohydrates in Complex Formation. J. Am. Chem. Soc. 1993, 115, 7962 - 7970.

(33) Nimlos, M. R.; Blanksby, S. J.; Qian, X.; Himmel, M. E.; Johnson, D. K. Mechanisms of Glycerol Dehydration. J. Phys. Chem. A 2006, 110, 6145 - 6156.

(34) Niederhoffer, E. C.; Timmons, J. H.; Martell, A. E. Thermodynamics of Oxygen Binding in Natural and Synthetic Dioxygen Complexes. Chem. Rev. 1984, 84, 137 - 203.

(35) Collman, J. P.; Decréau, R. A.; Dey, A.; Yang, Y. Water may inhibit oxygen binding in hemoprotein models. Proc. Natl. Acad. Sci. 2009, 106 (11), 4101 - 4105.

(36) Collman, J. P.; Gagnet, R. R.; Reedtt, C. A.; Robinson, W. T.; Rodley, G. A. Structure of an Iron(II) Dioxygen Complex; A Model for Oxygen Carrying Hemeproteins. Proc. Nat. Acad. Sci. U.S.A., 1974, 71 (4), 1326 - 1329.

(37) Martell, A. E.; Sawyer, D. T. (editors) Oxygen Complexes and Oxygen Activation by Transition Metals, 1988. ISBN: 978-1-4612-8263-1.

(38) Gupta, C. P. Role of Iron (Fe) in Body. IOSR J. Appl. Chem. (IOSR-JAC) 2014, 7 (11; Vers. II), 38 - 46. e-ISSN: 2278-5736.

(39) Fenical, W.; Kearns, D. R.; Radlick, P. The Mechanism of the Addition of Singlet Excited Oxygen to Olefins - Evidence for A 1,2-Dioxetane Intermediate. J. Amer. Chem. Soc. 1969, 91 (12), 3396 - 3398.

(40) Bartlett, P. D.; Mendenhall, G. D.; Schaap, A. P. Competitive modes of reaction of singlet oxygen. Ann. N. Y. Acad. Sci. 1970, 171, 79 - 88. 
(41) Kearns, D. R.; Fenical, W.; Radlick, P. Experimental and Quantum Chemical Investigation of Singlet Oxygen Reactions. Ann. N.Y. Acad. Sci. 1970, 171 (1), 34 - 49.

(42) Barton, D. H. R.; Martell, A. E.; Sawyer, D. T. The Activation of Dioxygen and Homogeneous Catalytic Oxidation; Editors Print ISBN 978-1-4613-6307-1 Online ISBN 978-1-4615-3000-8 Publisher Springer US Copyright Holder Plenum Press, New York, 1993.

(43) Aumann, R.; Wormann, H. Stufenweiser Abbau des Benzvalens in der Ligandensphäre eines Übergangsmetalls. Chem. Ber. 1979, 112, 1233 - 1251.

(44) Choudhary, V; Burnett, R. I.; Vlachos, D. G.; Sandler, S. I. Dehydration of Glucose to 5-(Hydroxymethyl)furfural and Anhydroglucose: Thermodynamic Insights. J. Phys. Chem. C 2012, 116, 5116 - 5120. 
1

2

3

4

5

6

7

8

9

10

11

12

13

14

15

16

17

18

19

20

21

22

23

24

25

26

27

28

29

30

31

32

33

34

35

36

37

38

39

40

41

42

43

44

45

46

47

48

49

50

51

52

53

54

55

56

57

58

59

60
TOC

$\underset{\text { glycerol }}{\stackrel{\mathrm{H}_{2} \mathrm{O}_{2}}{(\text { Fenton })}}{ }_{\mathrm{Fe}^{2+} \text { catalyst }}^{\mathrm{Mg}^{2+} \text { inhibition }}$ 